\title{
Drying Kinetics of Cecropia pachystachya Leaves
}

\author{
Alefe Viana Souza Bastos ${ }^{1}$ (D), Alisson Macendo Amaral ${ }^{1}$, \\ Flávio Henrique Ferreira Gomes ${ }^{1}$ (D), Warlles Xavier ${ }^{1}$, Osvaldo Resende ${ }^{1}$ \\ ${ }^{1}$ Instituto Federal de Educação, Ciência e Tecnologia Goiano, Rio Verde/GO, Brasil
}

\begin{abstract}
The species Cecropia pachystachya has important medicinal purposes and its leaves have been used in pharmaceutical research, so the drying of this product may help maintaining its chemical properties and ensure safe storage. Thus, the objective of this study was to select mathematical models to represent the drying kinetics of Cecropia pachystachya leaves, determine the effective diffusion coefficient and obtain the activation energy during drying at different temperatures. Leaves were dried in an oven under five temperature conditions $\left(40,50,60\right.$ and $\left.70{ }^{\circ} \mathrm{C}\right)$, until reaching hygroscopic equilibrium moisture content. Among the models analyzed, the Logarithmic model best represented the drying kinetics at temperatures of 40 and $60{ }^{\circ} \mathrm{C}$, whereas Modified Henderson \& Pabis and Dryceleaves represented temperatures of 50 and $70{ }^{\circ} \mathrm{C}$, respectively. The effective diffusion coefficient increased with increasing air temperature, and the activation energy for liquid diffusion in the drying process was $64.53 \mathrm{~kJ}$ mol-1.
\end{abstract}

Keywords: activation energy, embaúba, liquid diffusion, mathematical models, technology of forest products. 


\section{INTRODUCTION}

Cecropia pachystachya, popularly known as 'embaúba' in Brazil (Costa et al., 2011), is a medium size, pioneer tree of the Urticaceae family, with height from 4 to 8 meters. It prefers shaded, humid sites and has simple alternate leaves with 8 parts of $40 \mathrm{~cm}$, on average (Salman et al., 2008), with fast growth. Several studies using the Urticaceae family have been carried out due to its diversity of more than 2000 species and multiple medicinal uses. C. pachystachya became even more important for research due to the recent full characterization of its chloroplast DNA performed by Wu et al. (2017), which facilitates its use in studies related to the Urticaceae family, being very relevant in the most diverse areas of biology and medicine.

Five species of the genus occur in Brazil: Cecropia glaziou Sneth, C. hololeuca Miq, C. pachystachya Trécul, C. purpurascens Berg and C. sciadophylla Mart. C. pachystachya, popularly known as 'embaúba', which may reach $7 \mathrm{~m}$ in height with trunk diameter ranging from 15 to $25 \mathrm{~cm}$ (Bocchese et al., 2008).

C. pachystachya leaves have been widely studied aiming at new pharmaceutical products intended for the treatment of several diseases, through their antipathogenic compounds (Brango-Vanegas et al., 2014; Souza et al., 2014), functions such as antidepressant and protection from oxidative stress (Ortmann et al., 2016), anti-inflammatory and antioxidant, which can be attributed to the presence of phenolic compounds (Pacheco et al., 2014), more specifically flavonoids (Talhi \& Silva, 2012).

Drying of products with medicinal and pharmacological potential aims, among other aspects, to prepare them for safe storage, reduce enzymatic degradation, maintain chemical properties and operationalize their use in the industrial production with volume reduction (Goneli et al., 2014; Martins et al., 2015; Gasparin et al., 2017). Drying is also known as a process that extends the consumption period of plant materials (Horuz et al., 2017).

Various drying conditions should be tested to adjust the characteristics of each product during moisture content reduction, and theoretical mathematical models have been constantly used in literature to predict this phenomenon (Silva et al., 2017a; Maciel et al., 2017; Sonmete et al., 2017).

Given the above, this study aimed to select mathematical models capable of representing the drying kinetics of C. pachystachya leaves, as well as to determine and evaluate the effective diffusion coefficient, in addition to obtaining the activation energy for the drying process at different air temperatures.

\section{MATERIAL AND METHODS}

The experiment was conducted at the Laboratory of Post-harvest of Plant Products of the Federal Institute of Goiás - Campus of Rio Verde, using C. pachystachya ('embaúba') leaves collected from trees located in the preservation area of the campus at coordinates $17^{\circ} 48^{\prime} 3.52^{\prime \prime} \mathrm{S}, 50^{\circ} 54^{\prime} 27.33^{\prime \prime} \mathrm{W}$, and mean altitude of $720.0 \mathrm{~m}$ a.s.l., deposited in the herbarium of the Federal Institute of Goiás - Campus of Rio Verde under number 1009 and identified by specialist $\mathrm{PhD}$. André Luiz Gagliote.

Leaves were collected from the third middle of trees, between 6 and 7 a.m., time of maximum leaf turgor, and stored in plastic bags full of $\mathrm{CO}_{2}$, in order to inhibit water loss during transportation from the collection site to the processing laboratory. The plant material was subjected to cleaning and weighing prior to drying, using an analytical scale, with $0.01 \mathrm{~g}$ resolution, determining the wet weight of samples and weight of containers. Containers consisted of perforated metal trays with diameter of $28.0 \mathrm{~cm}$.

Three leaves per replicate were used due to the large leaf area of the species, with 3 replicates per temperature condition during drying in oven with forced air circulation, regulated at $40,50,60$ and $70^{\circ} \mathrm{C}$.

The gravimetric method was used to reduce the moisture content of C. pachystachya, with periodical weighing until hygroscopic equilibrium, when constant weight was achieved during the drying process. Before and after drying, moisture contents were determined by the method recommended by ASAE (2000), for fodder and leaves, in oven with 
forced air circulation at $103 \pm 1{ }^{\circ} \mathrm{C}$, for 24 hours. Room air temperature and relative humidity were monitored using a datalogger and the average relative humidity (RH\%) inside the oven during the drying process was estimated by the GRAPSI v. 8 software (Melo et al., 2004).

Experimental data were used to determine the moisture content ratios (RX) using Equation 1 (Sharaf-Eldeen et al., 1980).

$\mathrm{RX}=\frac{\mathrm{X}^{*}-\mathrm{X}_{\mathrm{e}}^{*}}{\mathrm{X}_{\mathrm{i}}^{*}-\mathrm{X}_{\mathrm{e}}^{*}}$

where: $\mathrm{RX}=$ moisture content ratio of the product, dimensionless; $\mathrm{X}^{\star}=$ moisture content of the product, decimal (d.b.); $\mathrm{X}_{\mathrm{i}}^{*}=$ initial moisture content of the product, decimal (d.b.); and $\mathrm{X}_{\mathrm{e}}^{*}=$ equilibrium moisture content of the product, decimal (d.b.).

Then, mathematical models commonly used in literature to represent the drying kinetics of agricultural products, as well as the model proposed in the present study, called Dryceleaves (Drying of Cecropia leaves), were fitted to data, as described in Table 1.

Models were fitted by nonlinear regression analysis using the Gauss-Newton method. Models were selected considering the magnitude of the following coefficients: determination $\left(\mathrm{R}^{2}\right)$, mean relative error $(\mathrm{P})$ (Equation 15) and mean estimated error (SE) (Equation 16), according to Smaniotto et al. (2017). For P, value $\leq 10 \%$ was considered as the main criterion to select the models, as well established in studies related to the drying of biological products.

$\mathrm{P}=\frac{100}{\mathrm{~N}} \Sigma \frac{|\mathrm{Y}-\hat{\mathrm{Y}}|}{\mathrm{Y}}$

$\mathrm{SE}=\sqrt{\frac{\sum(\mathrm{Y}-\hat{\mathrm{Y}})^{2}}{\mathrm{DF}}}$

where: $\mathrm{Y}=$ experimental value; $\hat{\mathrm{Y}}=$ value estimated by the model; $\mathrm{N}=$ number of experimental observations; $\mathrm{DF}=$ degrees of freedom of the model (difference between number of observations and number of parameters of the model).

Akaike's Information Criterion (AIC) and Schwarz's Bayesian Information Criterion (BIC), represented by Equations 17 and 18 (Burnham \& Anderson, 2004), respectively, were used as complementary and discriminating indicators. These indices were calculated by the $\mathrm{R}$ statistical program, so that the lower the values found, the better the fits of the model used in the study.

Table 1. Mathematical models used to predict the drying phenomenon of agricultural products.

\begin{tabular}{|c|c|c|c|}
\hline Model designation & Model & Equations & References \\
\hline Wang \& Singh & $\mathrm{RX}=1+\mathrm{a} \cdot \mathrm{t}+\mathrm{b} \cdot \mathrm{t}^{2}$ & (2) & Moyne et al. (1992) \\
\hline Verma & $\mathrm{RX}=\mathrm{a} \cdot \exp (-\mathrm{k} \cdot \mathrm{t})+(1-\mathrm{a}) \exp (-\mathrm{k} 1 . \mathrm{t})$ & (3) & Verma et al. (1985) \\
\hline Thompson & $\mathrm{RX}=\exp \left\{\left[-\mathrm{a}-(\mathrm{a} 2+4 . \mathrm{b} \cdot \mathrm{t})^{0.5}\right] / 2 . \mathrm{b}\right\}$ & $(4)$ & Thompson et al. (1968) \\
\hline Page & $\mathrm{RX}=\exp \left(-\mathrm{k} \cdot \mathrm{t}^{\mathrm{n}}\right)$ & (5) & Agrawal \& Singh (1978) \\
\hline Newton & $R X=\exp (-k \cdot t)$ & $(6)$ & O’Callaghan et al. (1971) \\
\hline Midilli & $\mathrm{RX}=\mathrm{a} \cdot \exp \left(-\mathrm{k} \cdot \mathrm{t}^{\mathrm{n}}\right)+\mathrm{b} \cdot \mathrm{t}$ & (7) & Arslan \& Özcan (2008) \\
\hline Logarithmic & $\mathrm{RX}=\mathrm{a} \cdot \exp (-\mathrm{k} \cdot \mathrm{t})+\mathrm{c}$ & $(8)$ & Yagcioglu et al. (1999) \\
\hline Henderson \& Pabis & $\mathrm{RX}=\mathrm{a} \cdot \exp (-\mathrm{k} . \mathrm{t})$ & (9) & Henderson (1974) \\
\hline Modified Henderson \& Pabis & $\mathrm{RX}=\mathrm{a} \cdot \exp (-\mathrm{k} . \mathrm{t})+\mathrm{b} \cdot \exp (-\mathrm{ko.t})+\mathrm{c} \cdot \exp (-\mathrm{k} 1 . \mathrm{t})$ & $(10)$ & Karathanos (1999) \\
\hline Two-term exponential & $R X=a \cdot \exp (-k \cdot t)+(1-a) \exp (-k \cdot a \cdot t)$ & $(11)$ & Sharaf-Eldeen et al. (1980) \\
\hline Two terms & $\mathrm{RX}=\mathrm{a} \cdot \exp (-\mathrm{ko.t})+\mathrm{b} \cdot \exp (-\mathrm{k} 1 . \mathrm{t})$ & $(12)$ & Henderson (1974) \\
\hline Approximation of Diffusion & $R X=a \cdot \exp (-k \cdot t)+(1-a) \exp (-k \cdot b \cdot t)$ & (13) & Kassem (1998) \\
\hline Dryceleaves (model proposed) & $\mathrm{RX}=\mathrm{a}+\mathrm{b} \cdot \mathrm{t}^{2.5}+\mathrm{c} \cdot \exp (-\mathrm{t})$ & (14) & \\
\hline
\end{tabular}

$\mathrm{t}=$ drying time; $\mathrm{h} ; \mathrm{k}, \mathrm{k}_{\mathrm{o}}, \mathrm{k}_{1}=$ drying constants, $\mathrm{h}^{-1} ; \mathrm{a}, \mathrm{b}, \mathrm{c}, \mathrm{n}=$ model coefficients; Eq. = equation. 


$$
\begin{aligned}
& \mathrm{AIC}=-2 \log \mathrm{L}+2(\mathrm{p}) \\
& \mathrm{BIC}=-2 \log \mathrm{L}+\mathrm{plog}(\mathrm{N}-\mathrm{r})
\end{aligned}
$$

where: $\mathrm{p}=$ number of model parameters to be estimated; $\mathrm{N}=$ total number of observations; $\mathrm{r}=$ rank of matrix $\mathrm{X}$ (incidence matrix for fixed effects); and $\mathrm{L}=$ maximum likelihood estimator of error variance.

The effective diffusion coefficient for C. pachystachya leaves was obtained by means of the Infinite Slab model, with approximation of 8 terms, as represented in Equation 19 (Smaniotto et al., 2017).

$$
\mathrm{RX}=\frac{\mathrm{X}^{*}-\mathrm{X}_{\mathrm{e}}^{*}}{\mathrm{X}_{\mathrm{i}}^{*}-\mathrm{X}_{\mathrm{e}}^{*}}=\frac{8}{\pi^{2}} \sum_{\mathrm{n}=0}^{\infty} \frac{1}{(2 \mathrm{n}+1)^{2}} \exp \left[-\frac{(2 \mathrm{n}+1)^{2} \cdot \pi^{2} \cdot \mathrm{D} \cdot \mathrm{t}}{4} \cdot\left(\frac{\mathrm{S}}{\mathrm{V}}\right)^{2}\right]
$$

where: $\mathrm{RX}=$ moisture content ratio of the product, dimensionless; $\mathrm{D}=$ effective diffusion coefficient, $\mathrm{m}^{2} \mathrm{~s}^{-1}$; $\mathrm{n}=$ number of terms; $\mathrm{S}=$ surface area of the product, $\mathrm{m}^{2}$; and $\mathrm{V}=$ leaf volume, $\mathrm{m}^{3}$.

Surface area was determined using the Image . $^{\circledR}$ software (Image Processing and Analysis in Java), which consists in an image integrator. Images were previously obtained by photographing the plant material on a white background of known scale. Leaf volume was determined considering the surface area and leaf thickness, measured using a digital caliper. The average surface area of leaves used was $1.45 \times 10^{-1} \mathrm{~m}^{2}$, with thickness of $4.60 \times 10^{-4} \mathrm{~m}$ and average volume of $6.66 \times 10^{-5} \mathrm{~m}^{3}$.

The Arrhenius expression describes the ratio between diffusion coefficient (D) and the variation in drying temperature according to the following expression.
$\mathrm{D}=\mathrm{D}_{\mathrm{o}} \cdot \exp \left(\frac{\mathrm{E}_{\mathrm{a}}}{\mathrm{R} \cdot \mathrm{T}_{\mathrm{a}}}\right)$

where: $\mathrm{D}=$ liquid diffusion coefficient, $\mathrm{m}^{2} \mathrm{~s}^{-1}$; $\mathrm{D}_{\mathrm{o}}=$ pre-exponential factor; $\mathrm{E}_{\mathrm{a}}=$ activation energy, $\mathrm{kJ} \mathrm{mol}^{-1}$; $\mathrm{R}=$ universal gas constant, equal to $8.314 \mathrm{~kJ} \mathrm{Kmol}^{-1}$; and $\mathrm{T}_{\mathrm{a}}=$ absolute temperature, $\mathrm{K}$.

\section{RESULTS AND DISCUSSION}

Reduction in the moisture content of leaves occurred within the range from 0.0017 to 0.0212 (dry basis), with drying times of $31,19,8$ and 2 hours for temperatures of $40,50,60$ and $70{ }^{\circ} \mathrm{C}$. Under these conditions, RH\% values estimated inside the oven were $24.84 \%\left(40{ }^{\circ} \mathrm{C}\right)$, $14.85 \%\left(50{ }^{\circ} \mathrm{C}\right), 7.79\left(60^{\circ} \mathrm{C}\right)$ and $4.93 \%\left(70{ }^{\circ} \mathrm{C}\right)$.

In the drying process, the elevation of air temperature increases the speed with which water is removed from the material and, for Gomes et al. (2017), this phenomenon is due to the increase in the difference of saturated air vapor pressure inside the plant product, resulting in water movement from inside the leaf to the drying air in a shorter period of time. This behavior has been reported in various studies, such as those conducted by Sahin \& Öztürk (2016) with fig fruits, Smaniotto et al. (2017) with sunflower grains, Horuz et al. (2017) with apricot fruits and Mghazli et al. (2017) with rosemary leaves.

Based on the mean relative error $(\mathrm{P}<10 \%)$ (Table 2$)$, being an eliminatory statistical parameter, theoretical models with the lowest magnitude at temperature of

\begin{tabular}{|c|c|c|c|c|c|c|c|c|}
\hline \multirow{2}{*}{ Models } & \multicolumn{2}{|c|}{$40^{\circ} \mathrm{C}$} & \multicolumn{2}{|c|}{$50{ }^{\circ} \mathrm{C}$} & \multicolumn{2}{|c|}{$60^{\circ} \mathrm{C}$} & \multicolumn{2}{|c|}{$70^{\circ} \mathrm{C}$} \\
\hline & $\mathbf{P}$ & $\mathbf{R}^{2}$ & $\mathbf{P}$ & $\overline{\mathbf{R}^{2}}$ & $\mathbf{P}$ & $\mathbf{R}^{2}$ & $\mathbf{P}$ & $\overline{\mathbf{R}^{2}}$ \\
\hline Approximation of diffusion & 7.47 & 0.997 & 31.82 & 0.999 & 10.96 & 0.996 & 329.36 & 0.991 \\
\hline Two terms & 8.75 & 0.998 & 52.29 & 0.981 & 11.25 & 0.996 & 53.52 & 0.999 \\
\hline Two-term Exponential & 13.57 & 0.997 & 53.48 & 0.980 & 20.02 & 0.995 & 329.35 & 0.995 \\
\hline Henderson \& Pabis & 21.60 & 0.997 & 52.29 & 0.981 & 23.65 & 0.995 & 319.13 & 0.992 \\
\hline Mod. Henderson \& Pabis & 21.60 & 0.997 & 6.84 & 1.000 & 84.72 & 0.701 & 53.47 & 0.999 \\
\hline Logarithmic & 7.93 & 0.998 & 119.96 & 0.992 & 9.94 & 0.996 & 56.07 & 0.999 \\
\hline Newton & 24.65 & 0.995 & 53.48 & 0.980 & 23.88 & 0.995 & 329.35 & 0.991 \\
\hline Page & 16.33 & 0.997 & 33.86 & 0.990 & 22.38 & 0.995 & 213.88 & 0.995 \\
\hline Thompson & 11.71 & 0.997 & 21.22 & 0.994 & 19.81 & 0.995 & 329.41 & 0.991 \\
\hline Verma & 7.48 & 0.997 & 31.81 & 0.998 & 10.96 & 0.996 & 54.48 & 0.999 \\
\hline Wang \& Singh & 90.26 & 0.922 & 680.33 & 0.399 & 125.40 & 0.922 & 176.83 & 0.923 \\
\hline Midilli & 10.86 & 0.998 & 75.54 & 0.992 & 12.93 & 0.997 & 85.30 & 0.999 \\
\hline Dryceleaves & 116.15 & 0.795 & 121.13 & 0.984 & 17.24 & 0.990 & 3.16 & 0.998 \\
\hline
\end{tabular}

Table 2. Mean relative error $(\mathrm{P})$ and determination coefficient $\left(\mathrm{R}^{2}\right)$ of mathematical models fitted in the drying of C. pachystachya leaves under different temperature conditions. 
$40{ }^{\circ} \mathrm{C}$ were Approximation of diffusion, Two terms, Logarithmic and Verma, whereas Modified Henderson \& Pabis, Logarithmic and Dryceleaves proved to be efficient at 50, 60 and $70{ }^{\circ} \mathrm{C}$, respectively. Thus, considering this parameter, only one model was fitted for the conditions of drying temperatures, except for $40{ }^{\circ} \mathrm{C}$. Satisfactory mean relative errors at $40^{\circ} \mathrm{C}$ have also been found in the drying of lemon balm using the Approximation of diffusion model (Barbosa et al., 2007) and 'timbó' (Serjania marginata Casar) using the Logarithmic model (Martins et al., 2015).

Determination coefficients were higher than 0.95, except for the Modified Henderson \& Pabis model at temperature of $60^{\circ} \mathrm{C}$, Wang \& Singh at all drying temperatures and the Dryceleaves model at $40{ }^{\circ} \mathrm{C}$ (Table 2). Although most of these models under the drying conditions of this study resulted in high $\mathrm{R}^{2}$ values, this coefficient alone is not determinant for the choice of nonlinear models fitted in the drying of C. pachystachya leaves. Complementary analyses with other parameters are necessary, as those used in studies with different plant materials and drying conditions (Darvishi et al., 2014; Camicia et al., 2015; Rosa et al., 2017; Moscon et al., 2017).

For the mean estimated error (SE), according to the selection of models by the $\mathrm{P}$ criterion, the Logarithmic model fitted best at temperatures of 40 and $60^{\circ} \mathrm{C}$, with values of $1.0 \times 10^{-4}$ and $1.8 \times 10^{-4}$. For the other temperature conditions, $\mathrm{SE}$ values were equal to $0.2 \times 10^{-4}$ for Modified Henderson \& Pabis at $50{ }^{\circ} \mathrm{C}$ and $0.8 \times 10^{-4}$ for the Dryceleaves model at temperature of $70^{\circ} \mathrm{C}$ (Table 3 ).
Considering $\mathrm{P}$ and SE, the Logarithmic model was the one that best represented the drying kinetics of Solanum lycocarpum A. St.-Hil leaves at temperatures of 40,50 and $60{ }^{\circ} \mathrm{C}$ (Reis et al., 2012) and the Modified Henderson \& Pabis was the best for Schinus terebinthifolius Raddi at temperatures of 40, 50, 60 and $70^{\circ} \mathrm{C}$ (Goneli et al., 2014), corroborating the present study, in which the drying kinetics was satisfactorily represented by the Logarithmic model at temperatures of 40 and $60^{\circ} \mathrm{C}$, and by the Modified Henderson \& Pabis model at temperature of $50^{\circ} \mathrm{C}$.

For Van Boekel (2008), the discrimination of models should be parsimonious and, when several models have reasonable fits, criteria such as Akaike's and Schwarz's Bayesian become useful tools to select the most efficient to predict a certain behavior. Thus, the AIC and BIC criteria were applied as a method to discriminate the most efficient model to represent the drying process of C. pachystachya at temperature of $40^{\circ} \mathrm{C}$, since several models have $\mathrm{P}<10 \%$.

According to Table 4, the Logarithmic model resulted in lower magnitude for AIC and BIC criteria, corroborating results found for the mean relative error. In addition, among the most adequate models for drying at $40{ }^{\circ} \mathrm{C}$, this as the lowest number of parameters and is recommended to represent moisture content reduction in C. pachystachya at this temperature. Following the classification order, the next models were Two terms, Verma and Approximation of diffusion.

The models with the best fits, suggested in the present study, are graphically represented in the drying curves

Table 3. Mean estimated error (SE) of mathematical models fitted in the drying of C. pachystachya leaves under different temperature conditions.

\begin{tabular}{|c|c|c|c|c|}
\hline \multirow{2}{*}{ Models } & $40^{\circ} \mathrm{C}$ & $50{ }^{\circ} \mathrm{C}$ & $60^{\circ} \mathrm{C}$ & $70^{\circ} \mathrm{C}$ \\
\hline & \multicolumn{4}{|c|}{ SE $\left(\times 10^{-4}\right)$} \\
\hline Approximation of diffusion & 1.4 & 0.5 & 1.9 & 6.5 \\
\hline Two terms & 1.1 & 7.6 & 1.8 & 0.7 \\
\hline Two-term Exponential & 1.7 & 8.1 & 2.4 & 5.6 \\
\hline Henderson \& Pabis & 1.8 & 7.6 & 2.5 & 5.4 \\
\hline Mod. Henderson \& Pabis & 2.0 & 0.2 & 198 & 1.2 \\
\hline Logarithmic & 1.0 & 3.3 & 1.8 & 0.6 \\
\hline Newton & 2.6 & 8.1 & 2.7 & 4.9 \\
\hline Page & 1.7 & 4.0 & 2.5 & 3.0 \\
\hline Thompson & 1.6 & 2.1 & 2.4 & 5.6 \\
\hline Verma & 1.4 & 0.5 & 1.8 & 0.6 \\
\hline Wang \& Singh & 43.5 & 252.3 & 72.2 & 5.2 \\
\hline Midilli & 1.0 & 3.3 & 1.7 & 0.7 \\
\hline Dryceleaves & 113.9 & 6.5 & 5.39 & 0.8 \\
\hline
\end{tabular}


Table 4. Akaike's Information Criteria (AIC) and Schwarz's Bayesian Information Criteria (BIC) of mathematical models fitted to the drying of C. pachystachya leaves at air temperature of $40^{\circ} \mathrm{C}$.

\begin{tabular}{|c|c|c|c|c|c|c|c|}
\hline \multicolumn{8}{|c|}{ Models } \\
\hline \multicolumn{2}{|c|}{ Approximation of diffusion } & \multicolumn{2}{|c|}{ Two terms } & \multicolumn{2}{|c|}{ Logarithmic } & \multicolumn{2}{|c|}{ Verma } \\
\hline AIC & BIC & AIC & BIC & AIC & BIC & AIC & BIC \\
\hline-209.04 & -202.28 & -218.88 & -210.43 & -220.66 & -213.90 & -209.05 & -202.30 \\
\hline
\end{tabular}

Table 5. Coefficients of mathematical models fitted to the drying of C. pachystachya leaves under different temperature conditions.

\begin{tabular}{ccc}
$\mathbf{T}\left({ }^{\circ} \mathbf{C}\right)$ & Models & Coefficients \\
40 & Logarithmic & $\mathrm{a}=0.9505^{\star *} ; \mathrm{k}=0.1718^{\star *} ; \mathrm{b}=0.0251^{\star *}$ \\
50 & Modified Henderson \& Pabis & $\mathrm{a}=-389.3411^{\star *} ; \mathrm{k}=0.4207^{\star *} ; \mathrm{b}=189.3947^{* *} ;$ \\
60 & Logarithmic & $\mathrm{d}=0.4045^{\star *} ; \mathrm{c}=200.9571^{\star *} ; \mathrm{e}=0.4374^{\star *}$ \\
70 & Dryceleaves & $\mathrm{a}=0.9505^{\star *} ; \mathrm{k}=0.1719^{\star *} ; \mathrm{b}=0.0252^{\star *}$ \\
\hline
\end{tabular}

**Significant difference at 0.01 probability level by $\mathrm{t}$-test; $\mathrm{T}=$ Drying air temperature.

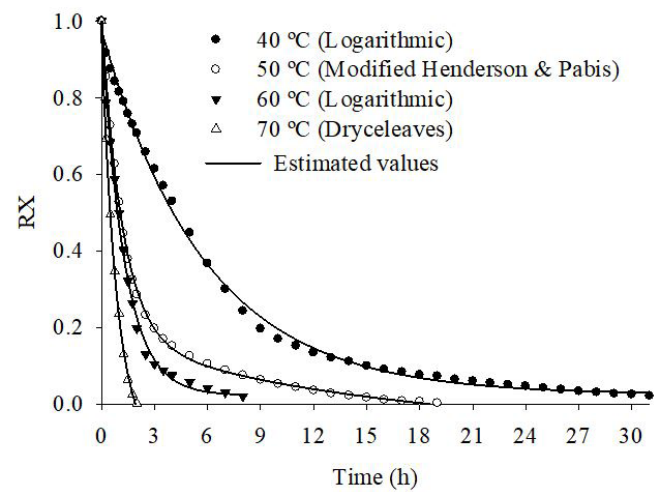

Figure 1. Drying curves experimentally obtained by Logarithm, Modified Henderson \& Pabis, Logarithm and Dryceleaves models at air drying temperatures of $40,50,60$ and $70{ }^{\circ} \mathrm{C}$, respectively.

according to Figure 1 and their respective coefficients are presented in Table 5. It is possible to observe that the chosen models had excellent adjustments with data observed in all drying air temperatures; it was also observed that as the drying temperature increased, the water removal rate also increased, which resulted in shorter drying times.

The diffusion coefficient (D) serves as an indicator of the speed with which water is removed from a product (Silva et al., 2017b), which can be influenced by the increase in drying air temperature (Smaniotto et al., 2017), and results in reduction of water viscosity, facilitating its removal from the capillaries of leaves.

An increase of $\mathrm{D}$ was observed as the drying air temperature increased during the drying of C. pachystachya leaves. Increments in D increased with increasing of air temperature (Figure 2A), corroborating several studies that have reported the same behavior with increase in drying air temperature (Rodríguez et al., 2014; Dai et al., 2015; Silva et al., 2015; Akpinar \& Toraman, 2016; Mghazli et al., 2017). Figure 2B presents the relationship between effective diffusivity and temperature, expressed by the Arrhenius equation.

Mghazli et al. (2017) in the drying of rosemary leaves found $\mathrm{D}$ variation from $2.55 \times 10^{-11}$ to $1.51 \times 10^{-10}$ $\mathrm{m}^{2} \mathrm{~s}^{-1}$, whereas in mint leaves, values ranged from $0.91 \times 10^{-11}$ to $10.41 \times 10^{-11} \mathrm{~m}^{2} \mathrm{~s}^{-1}$ (Motevali et al., 2016) and in lemon from $2.61 \times 10^{-11}$ to $9.24 \times 10^{-11} \mathrm{~m}^{2} \mathrm{~s}^{-1}$ (Tasirin et al., 2014). These results demonstrate effective diffusion coefficient values higher than those found in the present study, showing that C. pachystachya leaves have higher resistance to water loss from their inside to the drying air, compared to mint, rosemary and lemon leaves.

Such resistance is probably caused by the higher rigidity and thickness of $C$. pachystachya leaves, but Silva et al. (2017a) highlight the importance of also considering the chemical composition as a factor that influences diffusivity.

The activation energy is the minimum energy value required for the diffusion process to occur (Camicia et al., 2015) and its different values in various products can be attributed to their physical and biological characteristics (Martins et al., 2015). The activation energy for the drying of C. pachystachya leaves was 

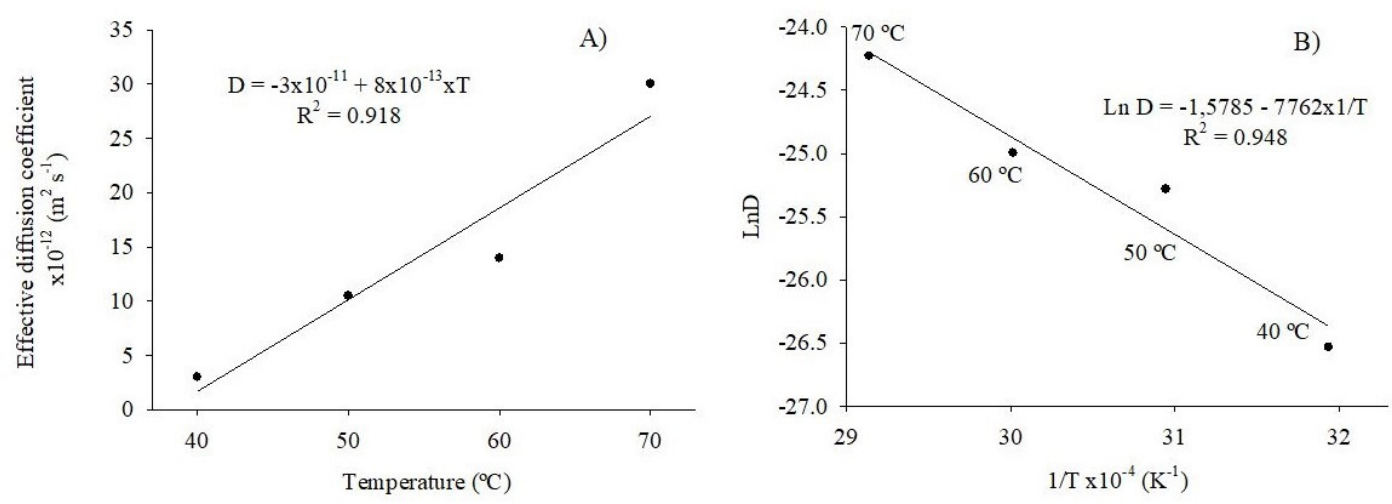

Figure 2. Effective diffusion coefficient as a function of drying temperature (A) and Arrhenius representation as a function of air temperature (B), obtained during the drying of C. pachystachya leaves.

$64.53 \mathrm{~kJ} \mathrm{~mol}^{-1}$, which is within the study temperature range, a result close to $63.17 \mathrm{~kJ} \mathrm{~mol}^{-1}$, found for mint leaves (Motevali et al., 2016), and $63.47 \mathrm{~kJ} \mathrm{~mol}^{-1}$, found for lemongrass (Martinazzo et al., 2007). In summary, all these results are important for understanding the drying process of C. pachystachya leaves in order to guarantee storage and processing in a safe way.

\section{CONCLUSION}

Among the models analyzed, the Logarithmic model best represented the drying kinetics at temperatures of 40 and $60^{\circ} \mathrm{C}$ in the drying of Cecropia pachystachya leaves, whereas Modified Henderson \& Pabis and Dryceleaves represented temperatures of 50 and $70{ }^{\circ} \mathrm{C}$, respectively. The effective diffusion coefficient increased with increasing air temperature with increments of $8.0 \times 10^{-13} \mathrm{~m}^{2} \mathrm{~s}^{-1}$ for every $10{ }^{\circ} \mathrm{C}$, and the activation energy for liquid diffusion in the drying process was $64.53 \mathrm{~kJ} \mathrm{~mol}^{-1}$.

\section{ACKNOWLEDGEMENTS}

The authors would like to thank to IF Goiano, CAPES, FAPEG, FINEP and CNPq for their financial support, which was indispensable to the execution of this study.

\section{SUBMISSION STATUS}

Received: 29 nov., 2018

Accepted: 7 july, 2019

\section{CORRESPONDENCE TO}

\section{Alefe Viana Souza Bastos}

Instituto Federal de Educação, Ciência e

Tecnologia Goiano, Campus Rio Verde, Rodovia Sul Goiana, Km 01, Zona Rural, CEP 75900-000, Rio Verde, GO, Brasil

e-mail: alefe_viana@hotmail.com

\section{REFERENCES}

Agrawal YC, Singh RP. Thin-layer drying studies on shortgrain rough rice. St. Joseph: ASAE; 1978.

Akpinar EK, Toraman S. Determination of drying kinetics and convective heat transfer coefficients of ginger slices. Heat and Mass Transfer 2016; 52(10): 2271-2281. http:// dx.doi.org/10.1007/s00231-015-1729-6.

American Society of Agricultural Engineers - ASAE. ASAE S358.2 DEC99: standards engineering practices data: moisture measurement-forages. St. Joseph: ASAE; 2000.

Arslan D, Özcan MM. Evaluation of drying methods with respect to drying kinetics, mineral content and color characteristics of rosemary leaves. Energy Conversion and Management 2008; 49(5): 1258-1264. http://dx.doi. org/10.1016/j.enconman.2007.08.005.

Barbosa FF, Melo EC, Santos RHS, Rocha RP, Martinazzo AP, Radunz LL et al. Evaluation of mathematical models for prediction of thinlayer drying of brazilian lemon-scented verbena leaves (Lippia alba (mill) N.E. Brown). Revista Brasileira de Produtos Agroindustriais 2007; 9(1): 73-80. http://dx.doi.org/10.15871/1517-8595/rbpa.v9n1p73-82.

Bocchese RA, Oliveira AKM, Laura VA. Germinação de sementes de Cecropia pachystachya Trécul (Cecropiaceae) em padrões anteriores e posteriores à passagem pelo trato 
digestório de aves dispersoras de sementes. Revista de Biologia e Ciências da Terra 2008; 8(8): 19-26.

Brango-Vanegas J, Costa GM, Ortmann CF, Schenkel EP, Reginatto FH, Ramos FA et al. Glycosylflavonoids from Cecropia pachystachya Trécul are quorum sensing inhibitors. Phytomedicine 2014; 21(5): 670-675. http:// dx.doi.org/10.1016/j.phymed.2014.01.001. PMid:24548722.

Burnham KP, Anderson DR. Multimodel inference: understanding AIC and BIC in model selection. Sociological Methods \& Research 2004; 33(2): 261-304. http://dx.doi. org/10.1177/0049124104268644.

Camicia RGM, Christ D, Coelho SEM, Camicia RFM. Modelagem do processo de secagem de sementes de feijão-caupi. Revista Caatinga 2015; 28(3): 206-214. http:// dx.doi.org/10.1590/1983-21252015v28n323rc.

Costa GM, Ortmann CF, Schenkel EP, Reginatto FH. An HPLC-DAD method to quantification of main phenolic compounds from leaves of Cecropia species. Journal of the Brazilian Chemical Society 2011; 22(6): 1096-1102. http://dx.doi.org/10.1590/S0103-50532011000600014.

Dai JW, Rao JQ, Wang D, Xie L, Xiao HW, Liu YH et al. Process-based drying temperature and humidity integration control enhances drying kinetics of apricot halves. Drying Technology 2015; 33(3): 365-376. http://dx.doi.org/10.10 80/07373937.2014.954667.

Darvishi H, Asl AR, Asghari A, Azadbakht M, Najafi G, Khodaei J. Study of the drying kinetics of pepper. Journal of the Saudi Society of Agricultural Sciences 2014; 13(2): 130-138. http://dx.doi.org/10.1016/j.jssas.2013.03.002.

Gasparin PP, Christ D, Coelho SRM. Secagem de folhas Menthapiperita em leito fixo utilizando diferentes temperaturas e velocidades de ar. Ciência Agronômica 2017; 48(2): 242-250.

Gomes NHF, Silva HC No, Alves JJL, Rodovalho RS, Sousa CM. Cinética de secagem de folhas de Cymbopogoncitratus. Engevista 2017; 19(2): 328-338. http://dx.doi.org/10.22409/ engevista.v19i2.837.

Goneli ALD, Vieira MC, Vilhasanti HCB, Gonçalves AA. Modelagem matemática e difusividade efetiva de folhas de aroeira durante a secagem. Pesquisa Agropecuária Tropical 2014; 44(1): 56-64. http://dx.doi.org/10.1590/ S1983-40632014000100005.

Henderson SM. Progress in developing the thin layer drying equation. Transactions of the ASAE 1974; 17(6): 1167-1168. http://dx.doi.org/10.13031/2013.37052.

Horuz E, Bozkurt H, Karataş H, Maskan M. Simultaneous application of microwave energy and hot air to whole drying process of apple slices: drying kinetics, modeling, temperature profile and energy aspect. Heat and Mass Transfer 2017; 54(2): 1-12.

Karathanos VT. Determination of water content of dried fruits by drying kinetics. Journal of Food Engineering
1999; 39(4): 337-344. http://dx.doi.org/10.1016/S02608774(98)00132-0.

Kassem AS. Comparative studies on thin layer drying models for wheat. In: Proceedings of the 13th International Congress of Agricultural Engineering; 1998; Rabat, Morocco. Rabat: ANAFID; 1998. p. 2-6.

Maciel RMG, Afonso MRA, Costa JMC, Severo LS, Lima ND. Mathematical modeling of the foam-mat drying curves of guava pulp. Revista Brasileira de Engenharia Agrícola e Ambiental 2017; 21(10): 721-725. http://dx.doi. org/10.1590/1807-1929/agriambi.v21n10p721-725.

Martinazzo AP, Corrêa PC, Resende O, Melo EC. Análise e descrição matemática da cinética de secagem de folhas de capim-limão. Revista Brasileira de Engenharia Agrícola e Ambiental 2007; 11(3):301-306. http://dx.doi.org/10.1590/ S1415-43662007000300009.

Martins EAS, Lage EZ, Goneli ALD, Hartmann CP Fo, Lopes JG. Cinética de secagem de folhas de timbó (Serjania marginata Casar). Revista Brasileira de Engenharia Agrícola e Ambiental 2015; 19(3): 238-244. http://dx.doi. org/10.1590/1807-1929/agriambi.v19n3p238-244.

Melo EC, Lopes DC, Corrêa PC. Grapsi - Programa computacional para o cálculo das propriedades psicrométricas do ar. Engenharia na Agricultura 2004; 12(2): 154-162.

Mghazli S, Ouhammou M, Hidar N, Lahnine L, Idlimam A, Mahrouz M. Drying characteristics and kinetics solar drying of Moroccan rosemary leaves. Renewable Energy 2017; 108: 303-310. http://dx.doi.org/10.1016/j. renene.2017.02.022.

Moscon ES, Martin S, Spehar CR, Devilla IA, Rodolfo F Jr. Cinética de secagem de grãos de quinoa (Chenopodium quinoa W.). Revista Engenharia na Agricultura 2017; 25(4): 318-325. http://dx.doi.org/10.13083/reveng.v25i4.773.

Motevali A, Chayjan RA, Salari K, Taghizadeh A. Studying the effect of different drying bed on drying characteristic of mint leaves. Chemical Product and Process Modeling 2016; 11(3): 231-239. http://dx.doi.org/10.1515/cppm2015-0045.

Moyne C, Kechaou N, Do Amaral Sobral PJ, Roques M, Cairault A, Bizot H. Séchage et mécanismes de transport de l'eau dans les gels. Entropie 1992; 28(167): 9-17.

O'Callaghan JR, Menzies DJ, Bailey PH. Digital simulation of agricultural dryer performance. Journal of Agricultural Engineering Research 1971; 16(3): 223-244. http://dx.doi. org/10.1016/S0021-8634(71)80016-1.

Ortmann CF, Réus GZ, Ignácio ZM, Abelaira HM, Titus SE, Carvalho P et al. Enriched flavonoid fraction from Cecropia pachystachya Trécul. leaves exerts antidepressantlike behavior and protects brain against oxidative stress in rats subjected to chronic mild stress. Neurotoxicity Research 2016; 29(4): 469-483. http://dx.doi.org/10.1007/ s12640-016-9596-6. PMid:26762362. 
Pacheco NR, Pinto NCC, Silva JM, Mendes RF, Costa JC, Aragão DMO et al. Cecropia pachystachya: a species with expressive in vivo topical anti-inflammatory and in vitro antioxidant effects. BioMed Research International 2014; 2014: 1. http://dx.doi.org/10.1155/2014/301294. PMid:24877079.

Reis PMFO, Reis RC, Devilla IA, Faria RQ, Lima AF Jr. Cinética de secagem de folhas de Solanum lycocarpum A. St.-Hil. (fruta-de-lobo). Revista Brasileira de Plantas Medicinais 2012; 14(3): 514-521. http://dx.doi.org/10.1590/ S1516-05722012000300014.

Rodríguez Ó, Santacatalina JV, Simal S, Garcia-Perez JV, Femenia A, Rosselló C. Influence of power ultrasound application on drying kinetics of apple and its antioxidante and microstructural properties. Journal of Food Engineering 2014; 129: 21-29.

Rosa JC, Mendonça AP, Oliveira AS, Ribeiro SB, Batista AR, Araújo MER. Drying kinetics of 'babassu' mesocarp. Revista Brasileira de Engenharia Agrícola e Ambiental 2017; 21(10): 709-714. http://dx.doi.org/10.1590/1807-1929/ agriambi.v21n10p709-714.

Sahin U, Öztürk HK. Experimental investigation of drying kinetics of pretreated and non-pretreated figs (Ficuscarica L.). Mugla Journal of Science and Technology 2016; 2(1): 20-26.

Salman AKD, López GFZ, Bentes-Gama MM, Andrade MS. Espécies arbóreas nativas da Amazônia Ocidental Brasileira com potencial para arborização de pastagens. Porto Velho: Embrapa; 2008. (Documentos; no. 127) [cited 2018 June 11]. Available from: https://www. infoteca.cnptia.embrapa.br/bitstream/doc/709707/1/ doc127arborizacaodepastagens.pdf

Sharaf-Eldeen YI, Blaisdell JL, Hamdy MY. A model for ear corn drying. Transactions of the ASAE 1980; 23(5): 1261-1265. http://dx.doi.org/10.13031/2013.34757.

Silva FP, Siqueira VC, Martins EAS, Miranda FMN, Melo RM. Thermodynamic properties and drying kinetics of Bauhinia forficata Link leaves. Revista Brasileira de Engenharia Agrícola e Ambiental 2017a; 21(1): 61-67. http:// dx.doi.org/10.1590/1807-1929/agriambi.v21n1p61-67.

Silva FP, Siqueira VC, Quinzani GA, Martins EAS, Goneli ALD. Drying kinetics of niger seeds. Engenharia Agrícola 2017b; 37(4): 727-738. http://dx.doi.org/10.1590/18094430-eng.agric.v37n4p727-738/2017.

Silva LA, Resende O, Virgolino ZZ, Bessa JFV, Morais WA, Vidal VM. Cinética de secagem e difusividade efetiva em folhas de jenipapo (Genipa americana L.). Revista
Brasileira de Plantas Medicinais 2015; 17(4): 953-963. http://dx.doi.org/10.1590/1983-084X/14_106.

Smaniotto TAS, Resende O, Sousa KA, Oliveira DEC, Campos RC. Drying kinetics of sunflower grains. Revista Brasileira de Engenharia Agrícola e Ambiental 2017; 21(3): 203-208. http://dx.doi.org/10.1590/1807-1929/agriambi. v2 $\ln 3$ p203-208.

Sonmete MH, Mengeş HO, Ertekin C, Özcan MM. Mathematical modeling of thin layer drying of carrot slices by forced convection. Food Measure 2017; 11(2): 629-638. http://dx.doi.org/10.1007/s11694-016-9432-y.

Souza DM, Tintino SR, Figuredo FG, Borges MC, Braga MFB, Felipe CFB et al. Atividade antibacteriana e moduladora de Cecropia pachystachya Trécul sobre a ação de aminoglicosídeos. Revista Cubana de Plantas Medicinales 2014; 19(1): 121-132.

Talhi O, Silva AMS. Advances in C-glycosylflavonoid research. Current Organic Chemistry 2012; 16(7): 859896. http://dx.doi.org/10.2174/138527212800194791.

Tasirin SM, Puspasari I, Lun AW, Chai PV, Lee WT. Drying of kaffir lime leaves in a fluidized bed dryer with inert particles: kinetics and quality determination. Industrial Crops and Products 2014; 61: 193-201. http://dx.doi. org/10.1016/j.indcrop.2014.07.004.

Thompson TL, Peart RM, Foster GH. Mathematical simulation of corn drying: a new model. Transactions of the ASAE 1968; 11(4): 582-586. http://dx.doi.org/10.13031/2013.39473.

Van Boekel MAJS. Kinetic modeling of food quality: a critical review. Comprehensive Reviews in Food Science and Food Safety 2008; 7(1): 144-158. http://dx.doi. org/10.1111/j.1541-4337.2007.00036.x.

Verma LR, Bucklin RA, Endan JB, Wratten FT. Effects of drying air parameters on rice drying models. Transactions of the ASAE 1985; 28(1): 296-301. http:// dx.doi.org/10.13031/2013.32245

Wu ZY, Du XY, Milne RI, Liu J, Li D-Z. Characterization of the complete chloroplast genome sequence of Cecropia pachystachya. Mitochondrial DNA. Part B, Resources 2017; 2(2): 735-737. http://dx.doi.org/10.1080/238023 59.2017 .1390420 .

Yagcioglu A, Degirmencioglu A, Cagatay F. Drying characteristics of laurel leaves under different drying conditions. In: Proceedings of the 7th International Congress on Agricultural Mechanization and Energy; 1999; Adana, Turkey. Adana: Faculty of Agriculture; 1999. p. 565-569 